Review Paper

\title{
Assessing the Environmental and Health Adverse Ef- fects of Mercury Released From Dental Amalgam: A Literature Review
}

\author{
Reyhaneh Aftabi $^{{ }^{*}}$ (D), Parisa Jafari ${ }^{1}$ (D), Marzieh Pirzadeh-Ashraf ${ }^{1}$ (iD
}

1. Department of Pediatric Dentistry, School of Dentistry, Kerman University of Medical Sciences, Kerman, Iran.

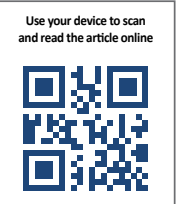

Citation Aftabi R, Jafari P, Pirzadeh-Ashraf M. Assessing the Environmental and Health Adverse Effects of Mercury Released From Dental Amalgam: A Literature Review. Journal of Advances in Environmental Health Research. 2021; 9(2):91-104. http://dx.doi.org/10.32598/JAEHR.9.2.1212

http://dx.doi.org/10.32598/JAEHR.9.2.1212

\section{Keywords:}

Mercury poisoning, Environment, Dentists, Pregnant women, Food contamination

\section{A B STRACT}

This paper reviews the most available data on the possible adverse effects of mercury released from amalgam that comprises 50\% pure mercury, $35 \%$ silver, $12-13 \%$ tin, $2 \%$ copper, and up to $1 \%$ zinc, indium, platinum, and palladium. Despite the possible health risks of mercury from amalgam on the nervous, respiratory, renal, and endocrine systems, it is used in some countries; however, Sweden, Denmark, Canada, the United States, and Japan have long banned the use of amalgam. Amalgam restorations are one of the main mercury-releasing sources (1800-2700 tons per year) of contamination. During chewing, grinding, brushing of teeth, breaking down of amalgam, and as the temperature of the oral environment increases, mercury vapor will be released. The mercury vapor enters the atmosphere, wastewater in dental offices, all systemic organs, especially the lower respiratory tract and can affect the renal-urinary system or enters breast milk, fetus, and finally, transmits to infants. The mercury level released from amalgam in blood, urine, hair, and nail of large populations of dentists, dental assistants, and pregnant women is higher than the safe levels. The main neurological and psychological effects of mercury vapor are sleep disorders, amnesia, mental disorders, hair loss, memory disturbances, multiple sclerosis, Parkinson's disease, kidney diseases, gene toxicity, Alzheimer's disease, Autism, skin allergies, cancer, infertility, low birth weight, and heart diseases. In order to avoid further amalgam risks to the dentists, dental assistants, pregnant women, and wildlife ecosystem, it is suggested to replace the dental amalgam with composite resins.

\section{Introduction}

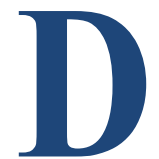

espite the fact that mercury amalgams share about $10 \%$ of the total world mercury consumption, they have almost been used for more than two centuries and as a result, the safeguard and environmental issues have recently been considered by the World Health Organization (WHO) and scientists $[1,2]$. Although there has been controversy over the systemic and environmental effects of dental amalgam, it is still considered a direct restorative material in some countries due to its strength,

"Corresponding Author:

Reyhaneh Aftabi, DDS.

Address: Iran, Kerman Province, Kerman, Jomhouri Islami Blvd, Shafa Ave, Kerman Faculty of Dentistry.

Phone: +98 (913) 1997861

E-mail: reyhane9495@gmail.com 
high corrosion resistance, long-term clinical durability, and cost-effectiveness. Nevertheless, replacing old amalgam restorations will release large amounts of mercury. Mercury is considered a toxic element (Tables 1 and 2), which can pose detrimental impacts on the human nervous system $[1,3]$, and even is regarded as the most dangerous metal after plutonium [1].

Amalgam is a combination of mercury (50\%) and other elements, including silver, tin, copper, and traces of zinc, indium, platinum, and palladium [4]. In addition to mercury, other associated heavy metals are also toxic and of environmental concern. Figures 1, 2 and 3 illustrate the different pathways, through which mercury enters the atmosphere, water, foods, and human organs.

The safe levels of total mercury, inorganic mercury, and methylmercury in the air are reported to be $2-10 \mathrm{ng} /$ $\mathrm{m}^{3}, 0.02 \mu \mathrm{g} / \mathrm{day}$, and $0.008 \mu \mathrm{g} /$ day, respectively [5]. The standard levels of total mercury, inorganic mercury, and methylmercury in drinking water are about $2 \mathrm{ppb}, 0.05$ $\mu \mathrm{g} /$ day, and $2.41 \mu \mathrm{g} /$ day, respectively [5]. With regard to foods, the mean mercury intake is generally within the range of 2-20 $\mu \mathrm{g} / \mathrm{day}$, and its level in solid and liquid foods is $0.50 .5 \mathrm{ppm}$; however, its average level in seafood (fish) ranges from 0.6 to $2.4 \mu \mathrm{g} /$ day $[5,6]$. Also, the average safe levels of total mercury in vegetables, fruits, cereals, wheat, and rice is $0.5,1.1,2.8,2.4 \mu \mathrm{g} / \mathrm{Kg}$, and 3 $\mathrm{ng} / \mathrm{g}$, respectively $[7,8]$.

Importantly, in contrast to other heavy metals, mercury has an affinity to be concentrated in proteins and finally, in the brain with a half-life of about 1-18 years $[9,10]$. Table 3 shows the total amount of mercury per year released from the dental clinics that enter into different environments, which is an environmental alert to human life.

According to Figures 1-3 there are several pathways that mercury and dental amalgam could harm the ecosystem, animals, and human beings [11-14].

The first main largest source of mercury is draining from the wastewaters of the dental clinics. The released mercury discharges into the Publicly-Owned Treatment Works (POTWs), where mercury separates into a mixture of sludge and biosolids $[15,16]$. The mercury-bearing sludges are then burned and the released mercury vapor enters the atmosphere, but the burnt biosolids are used as soil fertilizers [17]. Unfortunately, the fertilizers are enriched in mercury and are highly toxic to plants, human beings, and wildlife [18]. The second source of mercury is the excrete of amalgam-rich human wastes.
It is reported that the feces of patients with amalgam fillings contain more than ten times mercury than those that have not used mercury fillings [19]. This source contributes to huge amounts of mercury (more than 8 tons per year) in the U.S that discharges into the sewers, streams, lakes, and groundwaters [19]. The third source of mercury is released by cremation of human remains that discharges a large amount of mercury into the ecosystem and in particular, the soil [20]. Additional sources of mercury are also related to the high level of mercury vapor that diffuses inside and outside of the dental clinics or offices [21]. Table 2 displays the amount of mercury released from dental amalgam.

Despite considerable developments in amalgam technology, less attention has been given to the adverse health effects of mercury vapor released from amalgam in dental clinics. This study was done to introduce an overview of the environmental side effects of mercury and associated heavy metals released from amalgam fillings by the ecosystem and humans and to encourage the dentists to replace the amalgam with alternative restorative materials.

\section{Materials and Methods}

For data collection, English literature was searched using PubMed, Google Scholar, and ScienceDirect databases and the keywords, including "mercury released from amalgam", other toxic "heavy metals", and "side effects of amalgam" to survey the theme in recently published data up to the year 2020. The inclusion criterion was studies on the toxicity of mercury released from amalgam restorations associated with human health. Out of 254 obtained articles, only 74 studies were found relevant; thus, the published articles from 1982 to 2020 were evaluated. The exclusion criteria were articles that did not discuss widely side effects of mercury released from amalgam fillings or studies unrelated to human health risk effects. In this regard, the English abstracts and full texts of all the articles on the toxicity of mercury from amalgam and its adverse side effects were evaluated.

\section{Results and Discussion}

Table 3 represents the global risks of 260-340 metric tons/year mercury discharged into the environment that are the horrible alert to humans, wildlife, and plant [10]. This urges the Department of Environment in each city to measure periodically the level of mercury in air, drinking water, irrigating water, soil, cereal, wheat, rice, vegetables, fruits, meat, fish, and shrimp to determine the possible level of mercury contamination. Table 4 is 
Table 1. Relationship between mercury poisoning and other elements [4]

\begin{tabular}{ccc}
\hline Slightly Toxic & Toxic & Highly Toxic \\
\hline Lead & Thallium & Mercury \\
Arsenic & Arsenic & Cadmium \\
Tin oxide & Selenium & Arsenic \\
-- & Copper & Tin \\
\hline
\end{tabular}

based on the different levels of mercury from amalgam in a population of about 3091 dentists, 80 dental assistants, and 2779 pregnant women up to 2020; however, the complete data for each country were not available.

The data illustrate that the mean and range of mercury and methyl mercury concentrations in the blood, urine, hair, and nail in dentists, dental assistants, and in the blood and breast milk of pregnant women of different countries are mostly higher than the "reference levels" proposed by the WHO [25]. This suggests that the amounts of mercury vapor from dental clinics are at high levels [40]; thus, it will be transferred into the lungs, cells, tissues, brain, breast milk, and infants [40]. It is noteworthy that other heavy metal constituents of the mercury amalgam from the amalgam wastes, dental clinics, and wastewaters are also of environmental concern.40 In this context, Shraim et al. reported high mean values surpassing the safe levels of $\mathrm{Hg}(4.3 \mathrm{mg} / \mathrm{L}), \mathrm{Ag}$ (0.49 mg/L), Sn (3 mg/L), Cu (10 mg/L), Zn (76 mg/L), $\mathrm{Mg}(14.4 \mathrm{mg} / \mathrm{L}), \mathrm{Mn}(3 \mathrm{mg} / \mathrm{L}), \mathrm{Fe}(3 \mathrm{mg} / \mathrm{L}), \mathrm{Sr}(1.6$ $\mathrm{mg} / \mathrm{L})$, and $\mathrm{Ba}(6.9 \mathrm{mg} / \mathrm{L})$ in wastewaters drained from the dental clinics, which pose a real hazard to the environment [41]. Heavy metal constituents of some amalgams (Cr, Co, Cu, Ni, Pd, Sn, Zn, Ag, Pt, and $\mathrm{Au}$ ) are reported to cause allergic reactions and symptoms, such as localized chronic inflammation around restorations and oral lichen planus [42].

The WHO has reported serious adverse effects due to the use of mercury amalgam that releases 1800-2700 tons of mercury/year to the environment [43]. The first most exposed groups to mercury vapor are dentists and dental assistants because they are regularly and repeatedly working with the mercury amalgam and are at high health risks [44]. This is confirmed by the highest values of mercury (Table 4$)$ in the blood $(27.80 \mathrm{ug} / \mathrm{L})$ and urine $(64.46 \mathrm{ug} / \mathrm{L})$ of the Iranian dentists, almost 5 and 16 times higher than the "recommended safe levels" proposed by the WHO $[22,25]$. Kasraei et al. indicated higher mercury concentration in the urine of the Iranian dentists compared with the ordinary people, but the level is below the toxic threshold [9]. The highest mercury concentration in the hair of the Iranian dentists is also higher than the normal level suggested by the WHO [25, 26]; However, Zolfaghari et al. suggested that the use of masks by dentists may have a significant effect on lowering the absorbed dose of mercury by hair [27]. High levels of mercury are also reported in the blood (29.83

Table 2. Types of dental stimuli and the amount of mercury vapor released [4]

\begin{tabular}{cc}
\hline Items & Amount of Mercury (micrograms per cubic Meter) \\
\hline Amalgam in normal mode & 36 \\
Chewing foods & 68 \\
\hline Eating sweets & 270 \\
\hline Tooth brushing & 504 \\
\hline Completion and amalgam polishing & 597 \\
\hline Amalgam polishing with water spray & 4295 \\
\hline
\end{tabular}




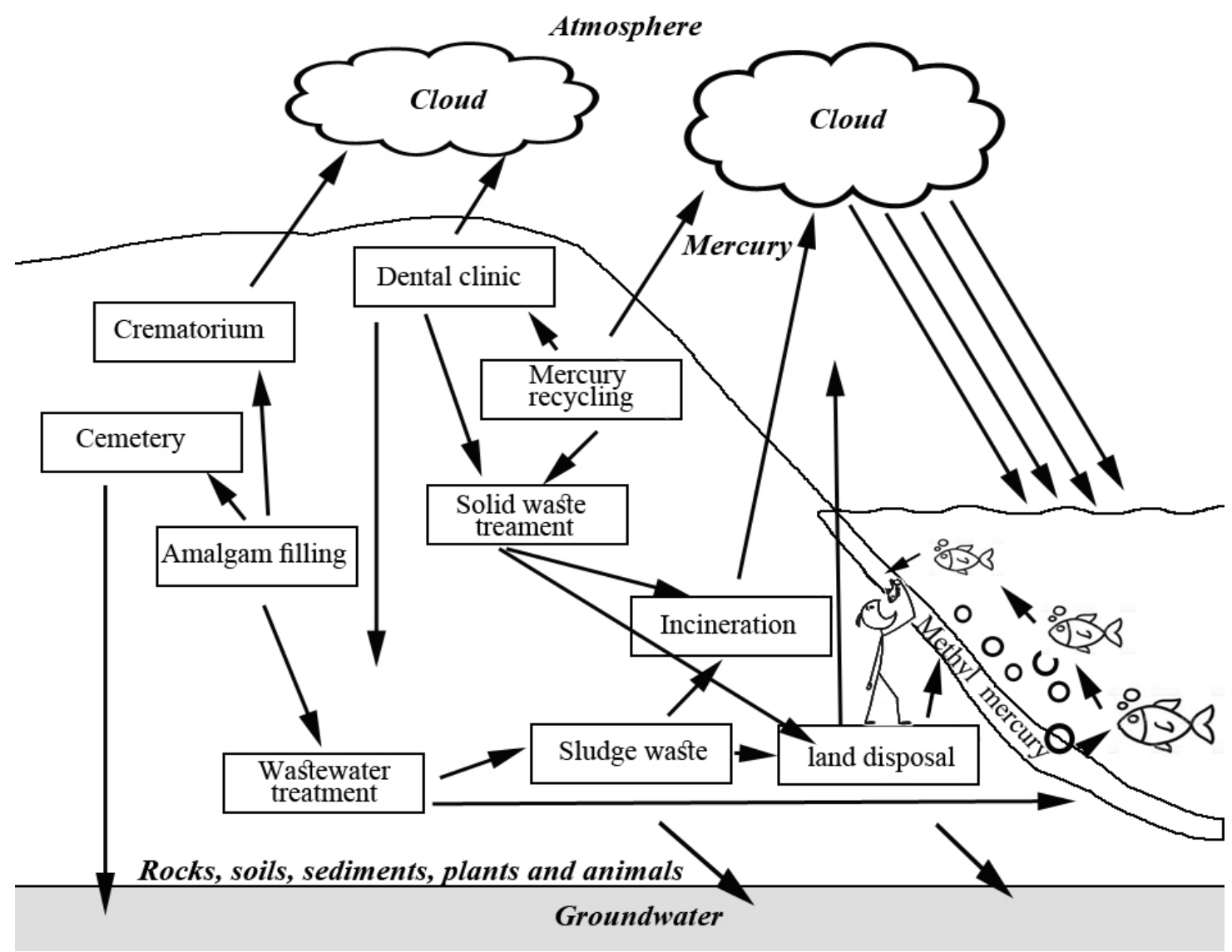

Figure 1. Mercury cycle from dental clinics to rocks, soil, water, sediments, plants, animals, and human beings [9]

$\mathrm{ug} / \mathrm{L})$ of dentists in Pakistan and urine $(12.40 \mathrm{ug} / \mathrm{L})$ of the dentists in the Netherlands $[35,38]$.

The second group at the risk of mercury toxicity includes pregnant women $[32,45]$. According to Table 4, the mercury level in pregnant women $(>$ having more than four amalgam restorations) is higher than those with no amalgam restorations. Mirza Koochaki Borujeni et al. also reported a significant relationship between dental surfaces restored with amalgam and mercury concentration in breast milk [46]. A comparative test of mercury levels in the blood of 1117 pregnant women (with more

Table 3. The amount of mercury used in dentistry and the pathways, through which enters the environment [10]

\begin{tabular}{cc}
\hline Global Releases/Pathways & Mercury (Metric Tons/Year) \\
\hline Atmosphere & $50-70$ \\
Surface water & $20-25$ \\
Groundwater & $75-100$ \\
Soil & $40-50$ \\
\hline Recycling of dental amalgam & $40-50$ \\
Sequestered, Secure disposal & $260-340$ \\
\hline
\end{tabular}




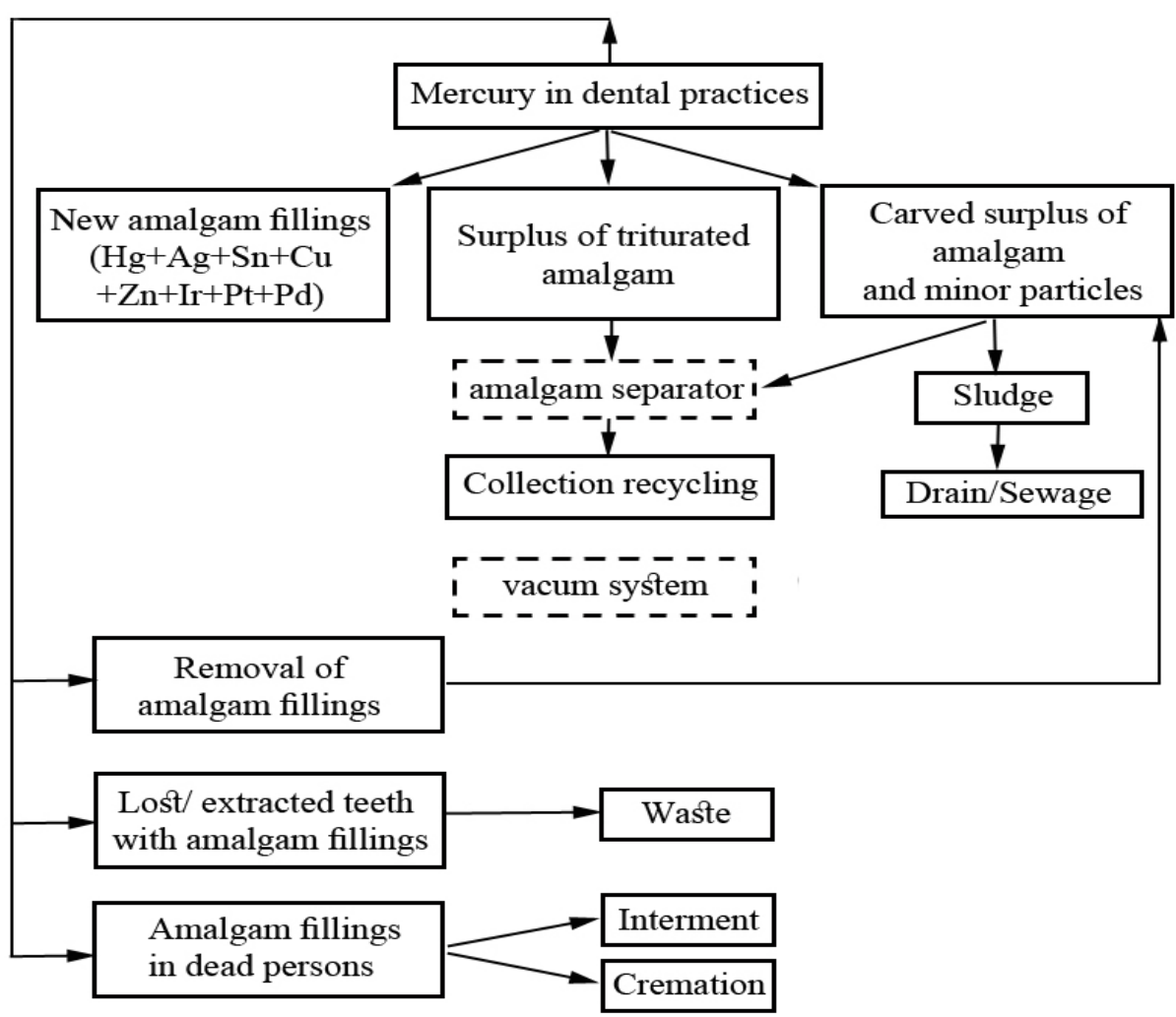

Figure 2. Mercury pathways released from amalgam in dental clinics [12]

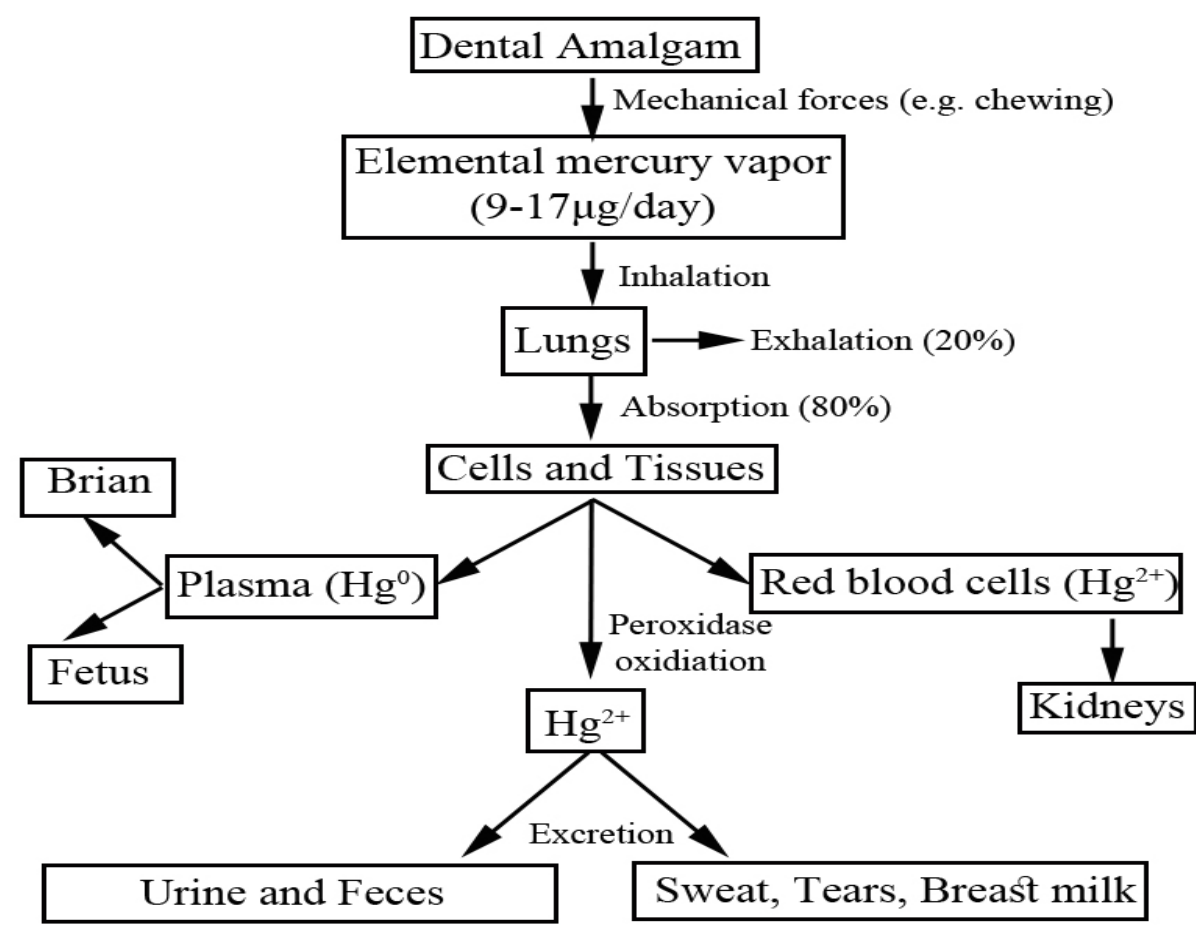

Figure 3. Mercury vapor cycle released from dental amalgams and entering the human body [13, 14] 
Table 4. Mercury and methyl mercury* concentrations in blood, hair, nail, and urine of dentists, dental assistants, and pregnant women

\begin{tabular}{|c|c|c|c|c|c|c|c|}
\hline \multirow{3}{*}{ Country } & \multirow{3}{*}{ Specimen } & \multicolumn{5}{|c|}{ Mean (Range) } & \multirow{3}{*}{$\begin{array}{l}\text { WHO } \\
\text { (2003) }\end{array}$} \\
\hline & & \multirow{2}{*}{ Control } & \multirow{2}{*}{ Dentists } & \multirow{2}{*}{$\begin{array}{c}\text { Dental } \\
\text { Assistants }\end{array}$} & \multicolumn{2}{|c|}{ Pregnant Women or Mothers } & \\
\hline & & & & & (No Amalgam) & (Amalgam >4) & \\
\hline \multirow{5}{*}{$\begin{array}{c}\text { Iran } \\
{[22-27]}\end{array}$} & Blood $(\mu \mathrm{g} / \mathrm{L})$ & - & $15(4.15-27.80)$ & - & - & - & 5 \\
\hline & Urine $(\mu \mathrm{g} / \mathrm{L})$ & - & $17.13(3.11-57.2)$ & - & - & - & 4 \\
\hline & Nail ( $\mu \mathrm{g} / \mathrm{g})$ & - & $3.54(3.53-3.56)$ & - & - & - & 2 \\
\hline & Hair $(\mu \mathrm{g} / \mathrm{g})$ & - & $2.84(0.09-25.43)$ & - & $0.32(0.13-1.7)$ & $0.46(0.11-3.57)$ & 2 \\
\hline & $\begin{array}{l}\text { Breast milk } \\
\quad(\mu \mathrm{g} / \mathrm{L})\end{array}$ & & & & 2.87 & 13.33 & 0.5 \\
\hline \multirow{5}{*}{$\begin{array}{c}\text { Glasgow, } \\
\text { Scotland } \\
\text { [28] }\end{array}$} & $\begin{array}{l}\text { Head hair } \\
(\mu \mathrm{g} / \mathrm{g})\end{array}$ & 4 (1.2-9.9) & $9.6(1.2-160)$ & $9.4(1.9-288)$ & - & - & - \\
\hline & $\begin{array}{l}\text { Public hair } \\
(\mu \mathrm{g} / \mathrm{g})\end{array}$ & $1.4(0.7-6.5)$ & $3.5(0.7-404)$ & $2.9(0.6-27)$ & - & - & - \\
\hline & $\begin{array}{l}\text { Finger nails } \\
\quad(\mu \mathrm{g} / \mathrm{g})\end{array}$ & $3.4(1.4-15)$ & $68(2.7-3070)$ & $16.9(1.3-2580)$ & - & - & - \\
\hline & $\begin{array}{l}\text { Blood (ng/g) } \\
\text { d.w. }\end{array}$ & $129(100-154)$ & $227(67-518)$ & - & - & - & - \\
\hline & $\begin{array}{l}\text { Blood }^{*} \\
\text { (ng/g) d.w. }\end{array}$ & $5.7^{*}(1.9-13.7)^{*}$ & $27^{*}(8.5-69.5)^{*}$ & - & - & - & - \\
\hline \multirow{5}{*}{$\begin{array}{l}\text { U.S.A } \\
\text { [28-31] }\end{array}$} & $\begin{array}{l}\text { Blood } \\
\text { (ng/mL) }\end{array}$ & $2.5(0-5)$ & $8.2(0-31)$ & & & & \\
\hline & $\begin{array}{l}\text { Urine } \\
\text { (ng/mL) }\end{array}$ & 3.4 & 15.3 & & & & \\
\hline & $\begin{array}{l}\text { Saliva } \\
\text { (ng/mL) }\end{array}$ & 15 & 161 & & & & \\
\hline & $\begin{array}{c}\text { Maternal } \\
\text { blood }(\mu \mathrm{g} / \mathrm{L})\end{array}$ & - & & & & 1.7 & \\
\hline & $\begin{array}{l}\text { Cord blood } \\
(\mu \mathrm{g} / \mathrm{L})\end{array}$ & - & & & & 4.3 & \\
\hline
\end{tabular}




\begin{tabular}{|c|c|c|c|c|c|c|c|}
\hline \multirow{3}{*}{ Country } & \multirow{3}{*}{ Specimen } & \multicolumn{5}{|c|}{ Mean (Range) } & \multirow{3}{*}{$\begin{array}{l}\text { WHO } \\
(2003\end{array}$} \\
\hline & & \multirow{2}{*}{ Control } & \multirow{2}{*}{ Dentists } & \multirow{2}{*}{$\begin{array}{c}\text { Dental } \\
\text { Assistants }\end{array}$} & \multicolumn{2}{|c|}{ Pregnant Women or Mothers } & \\
\hline & & & & & (No Amalgam) & (Amalgam >4) & \\
\hline \multirow{2}{*}{$\begin{array}{l}\text { England } \\
{[32,33]}\end{array}$} & $\begin{array}{c}\text { Urine } \\
(\mu \mathrm{mol} / \mathrm{mol})\end{array}$ & - & 1.73 & - & - & - & - \\
\hline & Blood $(\mu \mathrm{g} / \mathrm{L})$ & - & - & - & 1.84 & 2.28 & - \\
\hline \multirow{4}{*}{$\begin{array}{c}\text { Canada } \\
\text { [31] }\end{array}$} & $\begin{array}{c}\text { Maternal } \\
\text { blood }(\mu \mathrm{g} / \mathrm{L})\end{array}$ & & & & & 5.41 & \\
\hline & $\begin{array}{c}\text { Maternal } \\
\text { blood }^{*}(\mu \mathrm{g} / \mathrm{L})\end{array}$ & & & & & 4.32 & \\
\hline & $\begin{array}{l}\text { Cord blood } \\
(\mu \mathrm{g} / \mathrm{L})\end{array}$ & & & & & 10.96 & \\
\hline & $\begin{array}{l}\text { Cord blood } \\
(\mu \mathrm{g} / \mathrm{L})\end{array}$ & & & & & 9.73 & \\
\hline \multirow{2}{*}{ Egypt [34] } & $\begin{array}{l}\text { Blood } \\
(\mu \mathrm{g} / \mathrm{L})\end{array}$ & & 7.74 & & & & \\
\hline & $\begin{array}{l}\text { Urine } \\
(\mu \mathrm{g} / \mathrm{L})\end{array}$ & & 10.02 & & & & \\
\hline $\begin{array}{c}\text { Pakistan } \\
\text { [35] }\end{array}$ & $\begin{array}{l}\text { Blood } \\
(\mu \mathrm{g} / \mathrm{L})\end{array}$ & & 29.83 & & & & \\
\hline \multirow{2}{*}{$\begin{array}{c}\text { Turkey } \\
{[36,37]}\end{array}$} & $\begin{array}{l}\text { Blood } \\
(\mu \mathrm{g} / \mathrm{L})\end{array}$ & & 35.7 & & & & \\
\hline & $\begin{array}{l}\text { Urine } \\
(\mu \mathrm{g} / \mathrm{L})\end{array}$ & & 6.29 & & & & \\
\hline \multirow{2}{*}{$\begin{array}{c}\text { Netherlands } \\
{[10,38]}\end{array}$} & $\begin{array}{l}\text { Blood } \\
(\mu \mathrm{g} / \mathrm{L})\end{array}$ & & 4 & & & & \\
\hline & $\begin{array}{l}\text { Urine } \\
(\mu \mathrm{g} / \mathrm{L})\end{array}$ & & 12.4 & & & & \\
\hline
\end{tabular}




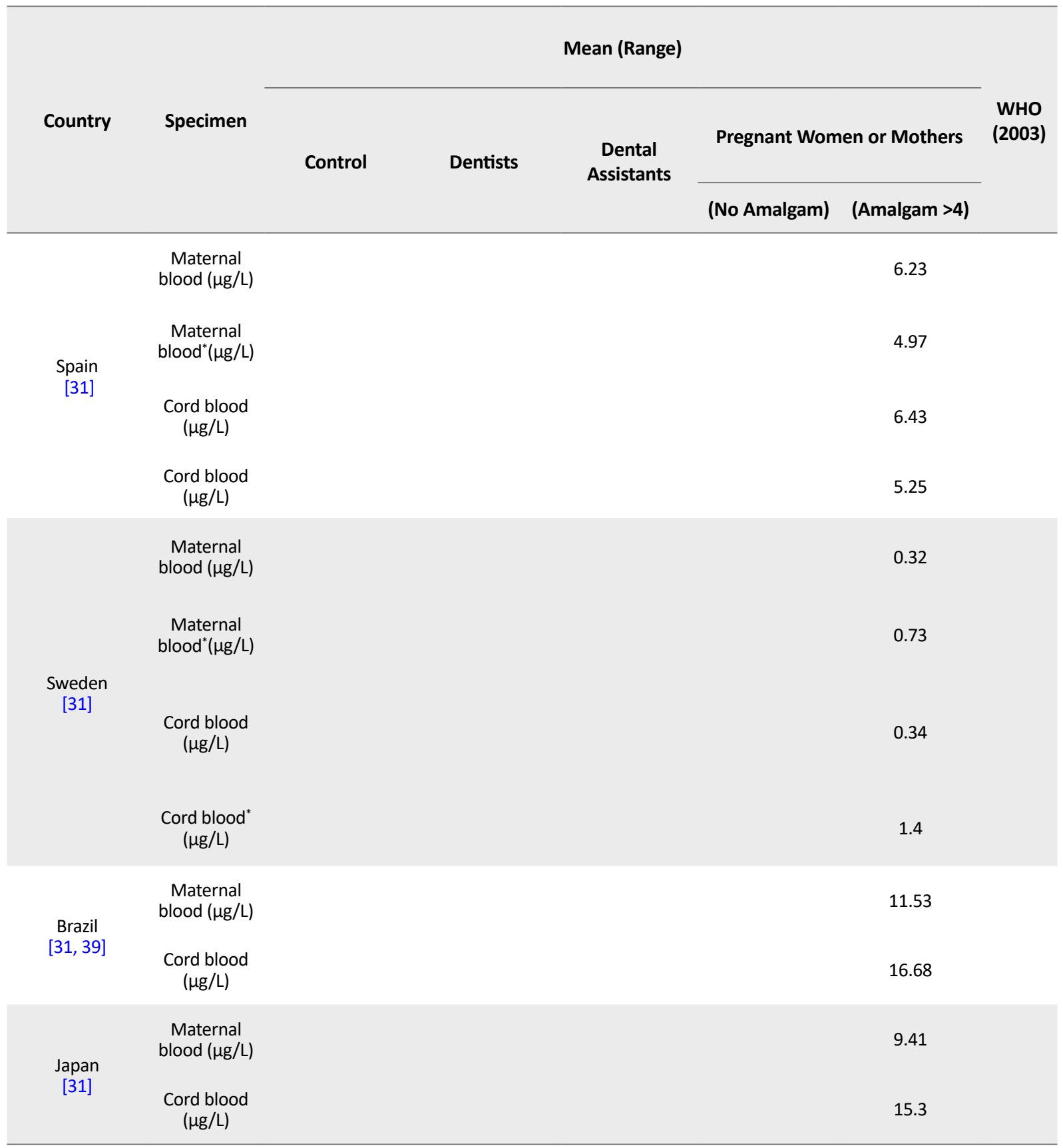

than 4 amalgam restorations) with a control group of 4468 women without amalgam restorations indicated that the first population had low birth weight infants $(<2500 \mathrm{~g})$, while the second population without amalgam restorations had normal infants weighing more than $2500 \mathrm{~g}$ [47].

Transferring mercury and methyl mercury from breast milk via maternal blood and cord blood to the placenta and fetus may cause serious health risks to the infants [31]. In this regard, the available data of mercury and methyl mercury in maternal blood and cord blood (Table 4) in some countries are above the WHO safe level [31].

The third group that is prone to the mercury resulted from amalgam restorations are children aged 6-10 years, but the average level of mercury in their urine is estimated to be $1.5 \mathrm{ug} / \mathrm{L}$, almost close to the WHO safe level [29]. It is accepted that mercury released from dental amalgam reacts with proteins, amino acids, pyrimidine, and nucleic acids [31], thus, may cause the following disorders: 
1) Blood disturbances in the brain: Mercury levels up to $1 \mathrm{mg} / \mathrm{L}$ in the blood can disrupt bloodstream flow to the brain for several hours and disrupts the activity of cellular mitochondria and the nervous system [48]. One of the most important parts of the brain that absorbs mercury is the pituitary gland that absorbs mercury 10 times more than the other parts of the brain [48]. Also, the increased serum levels of mercury are reported to be associated with an increase in white blood cells that may lead to leukemia [48].

2) Central Nervous System (CNS), kidney, and liver: CNS, followed by the kidneys and liver are at the greatest risk (the most affected organs) after exposure to mercury vapor and methyl mercury [48]. According to Hsu et al., patients having more dental amalgam fillings are 1.583 times more at the risk of Parkinson's Disease (PD) than the normal people without amalgam [49]. High level of mercury in kidneys produces tubular and glomerular damage [48, 50]. The psychopathological effects of excessive mercury absorption in the nervous system can cause ataxia, amnesia, irritability, depression, suicidal ideation, anger, shyness, and seizure [48]. because the half-life of mercury in nervous tissues is 27 days, it is highly dangerous for the brain [48].

3) Alzheimer's Disease (AD): Hsu et al. reported high concentrations of inorganic mercury in the brain tissues of AD patients [49]; thus, inorganic mercury could be a co-factor to cause AD [49]. Also, the association of mercury with selenium in selenoproteins may cause neurodegenerative disorders and disruption of redox regulation in the brain [51].

4) Autism: According to Mutter et al., the mercury released from dental amalgam fillings in maternal blood enters the placenta, fetus, and brains of infants and children leading to autism in children [51]. However, the mercury levels in the hair of autistic children are reported to be lower than the healthy children [51]. Based on the autopsy tests, there is a positive relationship between mercury concentration in the organs and brains of the children and infants and the number of dental amalgam restorations in their mother [51].

5) Multiple Sclerosis (MS): There are reports that some MS epidemics are caused by acute exposure to mercury vapor and lead toxicity [51]; however, the mercury levels in the liquor of MS patients having amalgam fillings are reported to be 7.5 times higher than the normal people [51]. In contrast, after removal of amalgam fillings, the MS patients have been reported to be less depressed and with a better psychotic social behavior [52]. A rare case of MS is amyotrophic lateral sclerosis, in which, high dose of mercury released from amalgam is absorbed by neurons that cause oxidative stress. A woman having 34 amalgams in Sweden had amyotrophic lateral sclerosis, but she became healthy after removing her amalgams and treating with selenium and vitamin $\mathrm{E}$ [52].

6) Infertility: Infertility is another health risk that is reported to occur in women with numerous amalgam fillings, but the rate of infertility in dental assistants, who are commonly exposed to mercury released from dental amalgam is more than the other populations [52].

7) Skin allergies: This side effect of mercury amalgam is known as lichen planus lesions or contact allergies, which are more common in the skin and rarely occur in the oral mucosa [53]. Prolonged contact of the amalgam with the oral mucosa is necessary for the development of lichenoid lesions [54]. Marell et al. suggested that by replacing the amalgam restorations with alternative restorative materials, the rate of reduction of contact lichenoid lesions increases significantly [55]. Most of the allergic reactions are caused by heavy metal constituents of amalgam, in particular, $\mathrm{Cr}, \mathrm{Co}, \mathrm{Cu}, \mathrm{Ni}, \mathrm{Pd}, \mathrm{Sn}, \mathrm{Zn}$, $\mathrm{Ag}$, and Pt [42].

8) Heart diseases: The mercury level in heart muscle biopsies is shown to be 22,000 times higher than the normal control people [52]. The high mercury levels lead to high blood pressure and each microgram of mercury that is secreted from urine may increase the rate of heart attack and circulatory diseases up to 1.36 times [52].

Other harmful health risks caused by a high dose of mercury vapor in dentists and assistant dentists include musculoskeletal disorders, hyperpigmentations, respiratory disorders, arrhythmia, hand tremor, upper extremities stiffness, neuropsychiatric symptoms of memory, sleep disorders, and decline in their long-term visual memory [9, 56-70].

Regarding the alternatives for dental amalgam, mercury-free dental materials have been widely used and available for many decades up to now [12,71]. These include composite resins, glass ionomer cement, compomers, gallium-nickel-copper-tin alloy, and gold foil [71]. Given the fact that the resin composites are tooth-colored materials, they are more popular highly because of their aesthetic properties, providing micromechanical bonding to the tooth structure, and easy tooth preparation than amalgam. However, some resin-based dental materials produce some contact allergens (e.g. formaldehyde) by degradation [72]. Glass-ionomers restorations are placed 
by hand instruments and after cleaning the decayed area of teeth, a high-viscosity glass-ionomer is then placed in the tooth cavity under the Alternative Restorative Treatment (ART) technique. In this method of restoration, no conventional dental equipment is needed [72].

\section{Conclusions}

This review demonstrated that the concentration of mercury from dental amalgam in the blood, urine, hair, and nail of dentists, assistant dentists, maternal blood, and breast milk is higher than the "reference level" suggested by the WHO; thus, dental amalgam poses a serious health risk. The health risk of mercury vapor caused by amalgam is more evident for pregnant women, lactating mothers, infants, and children. The serious adverse effects of mercury include sleep disorders, amnesia, mental disorders, hair loss, memory disturbances, multiple sclerosis, PD, kidney diseases, gene-toxicity, AD, Autism, skin allergies-cancer, infertility, low birth weight infants, and heart diseases. The WHO in 1997 has banned the use of amalgam fillings; however, the Environmental Protection Agency recommended the mandatory use of amalgam separators and alternative use of composite resins, glass ionomer cement, compomers, gallium-nickel-copper-tin alloy, and gold foil. Regarding the amalgam separators, researcher have been suggested that the efficiency of the separators has not fully been explored.

\section{Ethical Considerations}

\section{Compliance with ethical guidelines}

This article is a meta-analysis with no human or animal sample. There were no ethical considerations to be considered in this research.

\section{Funding}

This research did not receive any grant from funding agencies in the public, commercial, or non-profit sectors.

\section{Authors' contributions}

Conceptualization and supervision, methodology, investigation, data analysis: Reyhaneh Aftabi; Writing - original draft, writing - review \& editing, data collection: All authors.

\section{Conflict of interest}

The authors declare that they have no conflict of interest.

\section{Acknowledgments}

The authors appreciate the generous cooperation of their co-workers at Kerman University of Medical Sciences, Iran. We highly appreciate anonymous reviewers and contributors for insightful and constructive comments that significantly improved the quality of the manuscript

\section{References}

[1] Jirau-Colón H, González-Parrilla L, Martinez-Jiménez J, Adam W, Jiménez-Velez B. Rethinking the dental amalgam dilemma: An integrated toxicological approach. Int J Environ Res Public Health. 2019; 16(6):1036. [DOI:10.3390/ijerph16061036] [PMID] [PMCID]

[2] UNEP DTIE Chemicals Branch, WHO Department of Food Safety, Zoonoses and Foodborne Diseases. Guidance for identifying populations at risk from mercury exposure [Internet]. 2008 [Updated 2008 August]. Available from: https://www. who.int/foodsafety/publications/chem/mercuryexposure. pdf

[3] Mutter J, Naumann J, Schneider R, Walach H, Haley B. Mercury and autism: Accelerating evidence? Neuro Endocrinol Lett. 2005; 26(5):439-46. [PMID]

[4] McGuire T. The poison in your teeth: Mercury amalgam (silver) fillings ... hazardous to your health. Sebastopol: The Dental Wellness Institute; 2008. https://www.dentalwellness4u. com/ebooks/Poison_eBook.pdf

[5] World Health Organization. Mercury in drinking-water: Background document for development of $\mathrm{WHO}$ guidelines for drinking-water quality [Internet]. 2005 [Updated 2005]. Available from: https://www.who.int/water_sanitation_ health/dwq/chemicals/mercuryfinal.pdf

[6] World Health Organization. Environmental health criteria 118: Inorganic mercury [Internet]. 1991 [Updated 1991] Available from: http://apps.who.int/iris/bitstream/handle/10665/40626/IPCS_EHC_118.pdf;jsessionid=A55D94E14 01A4315B0F4B99886C3F4D2? sequence=1

[7] Palmieri JR, Guthrie T, Kaur G, Collins E, Benjamin B, Brunette J, et al. Implications and significance of mercury in rice. J Food Nutr Metab. 2020; 3(2):2-5. [DOI:10.31487/j. JFNM.2020.02.02]

[8] Jedrzejczak R. Determination of total mercury in foods of plant origin in Poland by cold vapour atomic absorption spectrometry. Food Addit Contam. 2002; 19(10):996-1002. [DOI:10.1080/02652030210151912] [PMID]

[9] Kasraei Sh, Mortazavi H, Vahedi M, Bakianian Vaziri P, Assary M. Blood mercury level and its determinants among dental practitioners in Hamadan, Iran. J Dent (Tehran). 2010; 7(2):55-63. [PMID] [PMCID]

[10] United Nations Environment Programme (UNEP). Lessons from countries phasing down dental amalgam use [Internet] 
2016 [Updated 2016 March]. Available from: https:/ / wedocs. unep.org/bitstream/handle/20.500.11822/31212/Dental.pdf

[11] Mason R, Pirrone N, editors. Mercury fate and transport in the global atmosphere: Emissions, measurements and models. New York: Springer-Verlag; 2009. [DOI:10.1007/978-0-38793958-2]

[12] Arenholt-Bindslev D. Dental amalgam - environmental aspects. Adv Dent Res. 1992; 6:125-30. [DOI:10.1177/089593 74920060010501] [PMID]

[13] Mitchell RJ, Okabe T. Setting reactions in dental amalgam. Part 1. Phases and microstructures between one hour and one week. Crit Rev Oral Biol Med. 1996; 7(1):12-22. [DOI:10.1177/ 10454411960070010101] [PMID]

[14] Timbrell JA, Seabra V, Waterfield CJ. The in vivo and in vitro protective properties of taurine. Gen Pharmacol Vascul Syst. 1995; 26(3):453-62 [DOI:10.1016/0306-3623(94)00203-Y]

[15] Wilburn DR. Changing patterns in the use, recycling, and material substitution of mercury in the United States: U.S. Geological Survey scientific investigations report 20135137 [Internet]. 2013 [Updated 2013 August 6]. Available from: https://pubs.er.usgs.gov/publication/sir20135137 [DOI:10.3133/sir20135137]

[16] Environmental Protection Agency. Effluent limitations guidelines and standards for the dental category [Internet]. 2017 [Updated 2017 July 5]. Available from: https://www. federalregister.gov/documents/2017/06/14/2017-12338/ effluent-limitations-guidelines-and-standards-for-the-dentalcategory

[17] Health and Environment Alliance (HEAL). 2. Mercury pollution - where does it come from? [Internet]. 2007 [Updated 2007]. Available from: https://www.env-health.org/IMG/ pdf/mercury_chapter2.pdf

[18] Björkman L, Sandborgh-Englund G, Ekstrand J. Mercury in saliva and feces after removal of amalgam fillings. Toxicol Appl Pharmacol. 1997; 144(1):156-62. [DOI:10.1006/ taap.1997.8128] [PMID]

[19] Larose C, Dommergue A, Marusczak N, Coves J, Ferrari CP, Schneider D. Bioavailable mercury cycling in polar snowpacks. Environ Sci Technol. 2011; 45(6):2150-6. [DOI:10.1021/ es103016x] [PMID]

[20] Hylander LD, Goodsite ME. Environmental costs of mercury pollution. Sci Total Environ. 2006; 368(1):352-70. [DOI:10.1016/j.scitotenv.2005.11.029] [PMID]

[21] Stone ME, Cohen ME, Debban BA. Mercury vapor levels in exhaust air from dental vacuum systems. Dent Mater. 2007; 23(5):527-32. [DOI:10.1016/j.dental.2006.03.011] [PMID]

[22] Jonidi Jafari A, Esrafili A, Moradi Y, Mahmoudi N. Mercury level in biological samples of dentists in Iran: A systematic review and meta-analysis. J Environ Health Sci Eng. 2020; 18(2):1655-69. [DOI:10.1007/s40201-020-00558-w] [PMID]

[23] Barghi M, Dahmardeh Behrooz R, Esmaili-Sari A, Ghasempouri SM. Mercury exposure assessment in Iranian pregnant women's hair with respect to diet, amalgam filling, and lactation. Biol Trace Elem Res. 2012; 148(3):292-301. [DOI:10.1007/ s12011-012-9384-y] [PMID]

[24] Norouzi E, Bahramifar N, Ghasempouri SM. Effect of teeth amalgam on mercury levels in the colostrums human milk in Lenjan. Environ Monit Assess. 2012; 184(1):375-80. [DOI:10.1007/s10661-011-1974-1] [PMID]

[25] Risher JF. Concise international chemical assessment document 50: Elemental mercury and inorganic mercury compounds: Human health aspects [Internet]. 2003 [Updated 2003]. Available from: https://www.who.int/ipcs/publications/cicad/en/cicad50.pdf

[26] Akbari M, Velayati Moghaddam F, Ahmadi A, Afshari R. [Evaluation of urinary mercury concentrations in general dentists and restorative specialists in Mashhad in 2010 (Persian)]. J Birjand Univ Med Sci. 2013; 19(4):416-21. http:/ /journal.bums.ac.ir/article-1-1216-en.html

[27] Zolfaghari Gh, Esmaeili Sari A, Ghasempouri SM, Faghihzadeh S. [Evaluation of mercury concentration in hair of dentists and survey of factors influencing its levels (Persian)]. J Environ Sci Technol. 2010; 12(3):149-60. https://jest.srbiau. ac.ir/article_153.html

[28] Chigbo FE, Smith RW, Shore FL. Uptake of arsenic, cadmium, lead and mercury from polluted waters by the water hyacinth Eichornia crassipes. Environ Pollut Ser A Ecol Biol. 1982; 27(1):31-6. [DOI:10.1016/0143-1471(82)90060-5]

[29] Oken E, Wright RO, Kleinman KP, Bellinger D, Amarasiriwardena $\mathrm{CJ}, \mathrm{Hu} \mathrm{H}$, et al. Maternal fish consumption, hair mercury, and infant cognition in a U.S. Cohort. Environ Health Perspect. 2005; 113(10):1376-80. [DOI:10.1289/ ehp.8041] [PMID] [PMCID]

[30] Goodrich JM, Chou HN, Gruninger SE, Franzblau A, Basu N. Exposures of dental professionals to elemental mercury and methylmercury. J Expo Sci Environ Epidemiol. 2016; 26(1):78-85. [DOI:10.1038/jes.2015.52] [PMID] [PMCID]

[31] World Health Organization. Children's exposure to mercury compounds [Internet]. 2010 [Updated 2010]. Available from: https://apps.who.int/iris/bitstream/handle/10665/44445/9789241500456_eng.pdf

[32] Golding J, Steer CD, Gregory S, Lowery T, Hibbeln JR, Taylor CM. Dental associations with blood mercury in pregnant women. Community Dent Oral Epidemiol. 2016; 44(3):216-22. [DOI:10.1111/cdoe.12208] [PMID] [PMCID]

[33] Morton J, Mason HJ, Ritchie KA, White M. Comparison of hair, nails and urine for biological monitoring of low level inorganic mercury exposure in dental workers. Biomarkers. 2004; 9(1):47-55. [DOI:10.1080/13547500410001670312] [PMID]

[34] Samir AM, Aref WM. Impact of occupational exposure to elemental mercury on some antioxidative enzymes among dental staff. Toxicol Ind Health. 2011; 27(9):779-86. [DOI:10.1177/0748233710397420] [PMID]

[35] Jamil N, Baqar M, Ilyas S, Qadir A, Arslan M, Salman M, et al. Use of mercury in dental silver amalgam: An occupational and environmental assessment. Biomed Res Int. 2016; 2016:6126385. [DOI:10.1155/2016/6126385] [PMID] [PMCID]

[36] Tezel H, Ertas OS, Erakin C, Kayali A. Blood mercury levels of dental students and dentists at a dental school. Br Dent J. 2001; 191(8):449-52. [DOI:10.1038/sj.bdj.4801205] [PMID]

[37] Karahalil B, Rahravi H, Ertas N. Examination of urinary mercury levels in dentists in Turkey. Hum Exp Toxicol. 2005; 24(8):383-8. [DOI:10.1191/0960327105ht541oa] [PMID] 
[38] Möller-Madsen B, Hansen JC, Kragstrup J. Mercury concentrations in blood from Danish dentists. Eur J Oral Sci. 1988 96(1):56-9. [DOI:10.1111/j.1600-0722.1988.tb01408.x] [PMID]

[39] Ventura DF, Simões AL, Tomaz S, Costa MF, Lago M, Costa MT, et al. Colour vision and contrast sensitivity losses of mercury intoxicated industry workers in Brazil. Environ Toxicol Pharmacol. 2005; 19(3):523-9. [DOI:10.1016/j. etap.2004.12.016] [PMID]

[40] Mutter J, Naumann J, Sadaghiani C, Walach H, Drasch G. Amalgam studies: Disregarding basic principles of mercury toxicity. Int J Hyg Environ Health. 2004; 207(4):391-7. [DOI:10.1078/1438-4639-00305] [PMID]

[41] Shraim A, Alsuhaimi A, Al-Thakafy JT. Dental clinics: A point pollution source, not only of mercury but also of other amalgam constituents. Chemosphere. 2011; 84(8):1133-9. [DOI:10.1016/j.chemosphere.2011.04.034] [PMID]

[42] Megremis S, Carey CM. Corrosion and tarnish of dental alloys [Internet]. 2006 [Updated 2006]. Available from: https:// tsapps.nist.gov / publication/get_pdf.cfm?pub_id=852614

[43] World Health Organization. Water, Sanitation and Health Team. Mercury in health care: Policy paper [Internet]. 2005 [Updated 2005]. Available from: https://apps.who.int/iris/ handle/10665/69129

[44] Nagpal N, Bettiol SS, Isham A, Hoang H, Crocombe LA. A review of mercury exposure and health of dental personnel. Saf Health Work. 2017; 8(1):1-10. [DOI:10.1016/j. shaw.2016.05.007] [PMID] [PMCID]

[45] Pugach S, Clarkson T. Prenatal mercury exposure and postnatal outcome: Clinical case report and analysis. Clin Toxicol. 2009; 47(4):366-70. [DOI:10.1080/15563650902866911] [PMID]

[46] Mirzakouchaki P, Rashidi F, Hassanli E, Karbalaiefar S. [Relationship between the number of tooth surfaces restored with amalgam and mothers' breast milk mercury levels: A preliminary study (Persian)]. J Isfahan Dent Sch. 2013, 8(7):645-51. https://jids.journalonweb.ir/index.php/jids/ article/view/572

[47] Hujoel PP, Lydon-Rochelle M, Bollen AM, Woods JS, Geurtsen W, de Aguila MA. Mercury exposure from dental filling placement during pregnancy and low birth weight risk. Am J Epidemiol. 2005; 161(8):734-40. [DOI:10.1093/aje/ kwi100] [PMID]

[48] Mutter J, Naumann J, Walach H, Daschner F. [Amalgam risk assessment with coverage of references up to 2005. Gesundheitswesen (German)]. 2005; 67(3):204-16. [DOI:10.1055/s-2005-857962] [PMID]

[49] Hsu YC, Chang CW, Lee HL, Chuang CC, Chiu HC, Li WY, et al. Association between history of dental amalgam fillings and risk of Parkinson's disease: A population retrospective cohort study in Taiwan. PLoS One. 2016; 11(12):e0166552. [DOI:10.1371/journal.pone.0166552] [PMID] [PMCID]

[50] Nicolae A, Ames H, Quiñonez C. Dental amalgam and urinary mercury concentrations: A descriptive study. BMC Oral Health. 2013; 13:44. [DOI:10.1186/1472-6831-13-44] [PMID] [PMCID]

[51] Mutter J, Daschner FD. Commentary regarding the article by Gottwald et al.: "Amalgam disease"--poisoning, allergy, or psychic disorder? Int. J. Hyg. Environ. Health 204,
223-229 (2001). Int J Hyg Environ Health. 2003; 206(1):69-70 [DOI:10.1078/1438-4639-00185] [PMID]

[52] Bailer J, Rist F, Rudolf A, Staehle HJ, Eickholz P, Triebig $\mathrm{G}$, et al. Adverse health effects related to mercury exposure from dental amalgam fillings: Toxicological or psychological causes? Psychol Med. 2001; 31(2):255-63. [DOI:10.1017/ S0033291701003233] [PMID]

[53] Greenberg MS, Glick M, Ship JA. Burket's oral medicine, diagnosis and treatment $.11^{\text {th }}$ ed. Hamilton: BC Decker Inc; 2008. pp. 88-89. https://books-library.net/files/downloadpdf-ebooks.org-1519307052N13O9.pdf

[54] Azizi A, Molaei N, Lavaf S, Semsar Y. [Oral lichen planus and dental amalgam restorations (Persian)]. J Res Dent Sci. 2012; 9(3):170-4. http://jrds.ir/article-1-159-fa.html

[55] Mårell L, Tillberg A, Widman L, Bergdahl J, Berglund A. Regression of oral lichenoid lesions after replacement of dental restorations. J Oral Rehabil. 2014; 41(5):381-91. [DOI:10.1111/joor.12151] [PMID]

[56] Fakour H, Esmaili-Sari A, Zayeri F. Scalp hair and saliva as biomarkers in determination of mercury levels in Iranian women: Amalgam as a determinant of exposure. J Hazard Mater. 2010; 177(1-3):109-13. [DOI:10.1016/j.jhazmat.2009.12.002] [PMID]

[57] Neghab M, Choobineh AR, Hassan Zadeh J, Ghaderi E. Symptoms of intoxication in dentists associated with exposure to low levels of mercury. Ind Health. 2011; 49(2):249-54. [DOI:10.2486/indhealth.MS1214] [PMID]

[58] Moen BE, Hollund BE, Riise T. Neurological symptoms among dental assistants: A cross-sectional study. J Occup Med Toxicol. 2008; 3:10. [DOI:10.1186/1745-6673-3-10] [PMID] [PMCID]

[59] Sletvold H, Svendsen K, Aas O, Syverson T, Hilt B. Neuropsychological function and past exposure to metallic mercury in female dental workers. Scand J Psychol. 2012; 53(2):136-43. [DOI:10.1111/j.1467-9450.2011.00929.x] [PMID] [PMCID]

[60] Thygesen LC, Flaschs EM, Hanehøj K, Kjuus H, Juel K. Hospital admissions for neurological and renal diseases among dentists and dental assistants occupationally exposed to mercury. Occup Environ Med. 2011; 68(12):895-901. [DOI:10.1136/oem.2010.064063] [PMID]

[61] Jones L, Bunnell J, Stillman J. A 30-year follow-up of residual effects on New Zealand School Dental Nurses, from occupational mercury exposure. Hum Exp Toxicol. 2007; 26(4):367-74. [DOI:10.1177/0960327107076824] [PMID]

[62] Aydin N, Karaoglanoglu S, Yigit A, Keles MS, Kirpinar I, Seven N. Neuropsychological effects of low mercury exposure in dental staff in Erzurum, Turkey. Int Dent J. 2003; 53(2):85-91. [DOI:10.1111/j.1875-595X.2003.tb00664.x] [PMID]

[63] Paknahad M, Mortazavi SM, Shahidi Sh, Mortazavi Gh, Haghani M. Effect of radiofrequency radiation from Wi-Fi devices on mercury release from amalgam restorations. J Environ Health Sci Eng. 2016; 14:12. [DOI:10.1186/s40201-0160253-z] [PMID] [PMCID]

[64] Lygre GB, Haug K, Skjaerven R, Björkman L. Prenatal exposure to dental amalgam and pregnancy outcome. Community Dent Oral Epidemiol. 2016; 44(5):442-9. [DOI:10.1111/ cdoe.12233] [PMID] 
[65] Sun YH, Nfor ON, Huang JY, Liaw YP. Association between dental amalgam fillings and Alzheimer's disease: A population-based cross-sectional study in Taiwan. Alzheimers Res Ther. 2015; 7(1):65. [DOI:10.1186/s13195-015-01501] [PMID] [PMCID]

[66] Anglen J, Gruninger SE, Chou HN, Weuve J, Turyk $\mathrm{ME}$, Freels $\mathrm{S}$, et al. Occupational mercury exposure in association with prevalence of multiple sclerosis and tremor among US dentists. J Am Dent Assoc. 2015; 146(9):659-68.e1. [DOI:10.1016/j.adaj.2015.05.016] [PMID]

[67] Ahlqwist M, Bengtsson C, Lapidus L. Number of amalgam fillings in relation to cardiovascular disease, diabetes, cancer and early death in Swedish women. Community Dent Oral Epidemiol. 1993; 21(1):40-4. [DOI:10.1111/j.1600-0528.1993. tb00717.x] [PMID]

[68] Moszczyński P. [Mercury and the risk of coronary heart disease (Polish)]. Przegl Lek. 2006; 63 Suppl 7:84-7. [PMID]

[69] Oliveira MT, Constantino HV, Molina GO, Milioli E, Ghizoni JS, Pereira JR. Evaluation of mercury contamination in patients and water during amalgam removal. J Contemp Dent Pract. 2014; 15(2):165-8. [DOI:10.5005/jp-journals-10024-1508] [PMID]

[70] Rothwell JA, Boyd PJ. Amalgam dental fillings and hearing loss. Int J Audiol. 2008; 47(12):770-6. [DOI:10.1080/14992020802311224] [PMID]

[71] Berniyanti T, Hariyani N. Side effects of mercury in dental amalgam. Dent J. 2008; 41(1):30-4. [DOI:10.20473/j.djmkg. v41.i1.p30-34]

[72] Tibau AV, Grube BD. Mercury contamination from dental amalgam. J Health Pollut. 2019; 9(22):190612. [DOI:10.5696/2156-9614-9.22.190612] [PMID] [PMCID] 
This Page Intentionally Left Blank 